\title{
CONCERNING A MINOR REFORM IN INDIANA.
}

THE legislature of Indiana, at its session of I 899, enacted a law which went through both houses quietly, arousing no opposition, and yet it is one which may bring about consequences of great moment to the state. Its title was "An Act to Regulate the Administration of the Relief of Poor Persons, and Prescribing Certain Duties of the Overseers of the Poor." × Its purpose was to bring the administration of poor relief in every township of the state into line with the most recent conceptions of the science of charity.

The act referred to was the last of a series of acts, and of an agitation for a reform which had been carried on patiently and quietly for ten years. It began with the first year's work of the Board of State Charities in I 889. The secretary of that board, desiring to collect statistics on the subject of outdoor relief, sent a circular to the trustees of the I,I07 townships, asking for a report upon their distribution of relief for the past year. Less than one hundred and fifty answers were received, and not more than one-fourth of these showed any intelligent appreciation of what was requested. The secretary proceeded to collect the information needed, as well as he could, from the county auditors. In most cases it was only by personal requests at the auditors' offices in the various county seats that correct and complete statistics could be had, and often not even then.

The information collected the first year was meager; it gave nothing but the gross sums charged up by the trustees from the county funds for the relief of the poor during the year. It was also possible in most cases to obtain the separate cost of medical outdoor relief, since in most counties, at that time, the board of commissioners made a contract with a physician for each township to furnish medical attendance and medicines to the poor of the township, for a fixed sum per annum.

${ }^{x}$ In the state of Indiana each township has one trustee who is ex officio the overseer of the poor in and for his township. 
Meager as were these first statistics, when the figures were put together and compared some very interesting facts were disclosed. The first fact noticed was that the total of outdoor relief for the state was much larger than the similar total for some other states, notably than that of Ohio, which had a million more people, the amount given per capita of the total population being more than double that in Ohio. The second fact noticed was that the amount of relief given in different counties bore no apparent relation to other conditions of the counties. It was expected that the counties containing the larger centers of population would show the largest per capita cost; that thriving agricultural communities would show by far the lowest cost. But none of these things was apparent. The county whose poor relief was proportionately the most costly gave nineteen times as much per capita as that in which it seemed the least costly. Yet they were both agricultural counties with no large towns. It began at once to appear certain that not the presence or absence of large towns, nor the irregularity of employment in certain manufacturing industries, nor the varying habits of the people - not these, nor any of them, was the chief cause in producing the varying effects shown, but chiefly, if not entirely, the cause was difference of administration. It seemed emphatically true that the counties which chose to manufacture paupers had many, and those which declined that industry had few.

The second annual report of the board presented an elaborate statement in the matter of poor relief. The expenditures of the counties were worked out into comparisons of total expense, of cost of the county asylum, the county orphans' home, and the outdoor relief, etc. When one county was shown to be giving to its poor no less than $\$ 1.07$ per capita of its total population, the county paper pointed with pride to the liberality of the public officials. It need not be said that it was a proadministration paper that did so.

Public attention was drawn slowly to the subject. In 1890 the state board called the first Indiana State Conference of Charities and Correction together. At this meeting the subject of outdoor relief elicited a long and interesting discussion. The 
story of the remarkable reduction of outdoor relief in Indianapolis was recounted as one of the world's most striking objectlessons in the administration of poor relief. ${ }^{x}$ A committee was appointed, consisting of three trustees, a county commissioner, and the secretary of the Board of State Charities, to present a careful report of the subject to the next conference.

The meeting at which this committee reported was a convention of township trustees and county commissioners. It was called by the Board of State Charities in I89I. The report of the special committee recounted some of the evils arising from misused poor relief and urged concerted action by the trustees. It recommended that the principles of scientific charity-full investigation, registration, coöperation of relief agencies, etc.should be adopted by public officials. The report alleged that, if this were done, a saving to the taxpayers of a sum anywhere from $\$ 50,000$ to $\$ 250,000$ per annum might be reasonably expected.

So far the results of the agitation for poor-relief reform seemed not very encouraging. Although the years I89I and I 892 were generally prosperous periods, still the total amount of poor relief increased. Then came the panic year, I893, and the increase was more rapid, as was shown in May, I894, at which date the county fiscal year in Indiana then closed.

The statistics collected up to I 894 were too general to afford a basis for action, or perhaps for very positive assertion. All that could be shown was the total outdoor relief disbursed in each township. In I 895 the legislature, on the request of the Board of State Charities, made a law requiring the trustees to report their relief to the county auditor in detail, quarterly, in duplicate, one copy of the report to be transmitted by the auditor to the Board of State Charities. Most of the trustees promptly obeyed, and a mass of detailed information about poor relief began to accumulate. Then it became possible to criticise the work in the townships, not merely the sums total, but the

${ }^{x}$ This occurred in $1876-80$, when an enterprising and intelligent trustee, using good business methods, reduced the annual distribution of outdoor relief in Center township, Marion county, from $\$ 85,000$ to less than $\$ 12,000$, without causing any additional suffering, and without increasing the population of the county poor asylum. 
individual cases being on record. The results published in the reports of the board form wonderfully interesting reading.

Still many trustees, and some auditors, refused or neglected to make reports until in 1897 two far-reaching and salutary laws were enacted. One of these required each township to pay for its own poor, by a special township levy each year, sufficient to reimburse the county for the amount it had advanced. The second provided a method to compel officials to do their duty, by a simple and easy process of impeachment, before the circuit court of their county. Since that session of the legislature no official has needed more than a citation of the impeachment law to spur him up to making all reports that the laws require.

With the full particulars from every township furnished in I 897 and I 898 , the facts began to show with sunlight clearness. It appeared that townships with conditions much alike varied enormously in the number of paupers relieved. In some, one person in every eight of the population received relief; in others only one person in 250 was on the poor books. The levy for poor relief in different townships varied from as low as 3 mills to as high as 30 cents on the $\$ 100$ of valuation. The conviction became incontestable that the cause of these differences anywhere, and of the excessive total everywhere, was to be sought in the varying efficiency of administration and nowhere else. This became so plain that the wayfaring man, though a fool, need not err therein.

So far in Indiana for very many years the township trustee had been almost a law unto himself. There has rarely been seen in a free government so striking an example of one-man power as was his before the reform acts of 1899 . It was the trustee's duty to levy taxes and to spend them with little check upon him but that of public opinion. He had charge of the schools, the roads, the poor, and a multitude of other things. He made contracts, borrowed money, issued bonds, and did almost all that any government does, and almost without check or control. For four years he was a dictator. He appointed teachers and, with his fellow-trustees, elected the county superintendent of schools. He nominated drainage commissioners and 
appointed highway supervisors. In theory he had to report to the county commissioners, but their authority and control were much hampered by both law and custom. It says much for the rugged good sense and honesty of the average Hoosier that with such a method the townships were, as a whole, decently managed, that serious scandals were few, that taxes were not crushing, that many trustees retired without having made a fortune during their four-years' term of office.

At last, in I899, arrived the favorable opportunity for reform. The State Board of Commerce - a body made up of representatives from the various commercial clubs, boards of trade, business-men's associations, etc., throughout the state-had been considering the need of reform of county and township government for some years. The president of the board, a far-seeing and most public-spirited man, believed that the time had come to reform the laws which, both for township and county affairs, were far from modern or scientific. He interested the chairman of the state committee of the party which had won the last election, and which therefore would command a majority in the legislature. The chairman called a meeting of members of the house and senate, representing each congressional district in the state. To this meeting the State Board of Commerce, the State Bar Association, and the State Federation of Labor each sent seven delegates.

The large committee met, talked, and chose a small executive committee. The latter subdivided itself, drafted bills, got them introduced, lobbied for them, fought for them in committees, and carried them to a splendid success.

The chief reforms proposed and adopted were of a very thorough character; the committees felt that they had their hands full without attending to minor matters. So far nothing had been done touching the poor relief. Then the chairman of the executive committee sent for a man who had occupied a prominent position for some years past in charity matters, both in the state and the nation, and asked him to accept the chairmanship of a special subcommittee, whose purpose should be to draft separate bills, if any were needed, for reforming the 
administration of public charity. This subcommittee consisted of four men: the one above mentioned, the secretary of the Board of State Charities, the secretary of the leading charity-organization society of the state, and an ex-township trustee who had discharged his duties as overseer of the poor with singular intelligence, zeal, and fidelity.

This subcommittee drafted three bills. One became the act mentioned in the first paragraph of this article, the second regulated the management of the county asylums for the poor, the third established county boards of charities and correction. All were successful and are now among the laws of the state.

The new laws went into effect in the summer of I899, and not until the close of the county fiscal year, on May 3I, I900, was it possible to form any accurate idea of their results. The law regulating outdoor relief prescribed the methods with which every student of economic science is familiar, when applied to city charities, under the name of "charity organization." That all the facts concerning poor people should be known to those who would really help them; that full and accurate records of such facts, of the help afforded, and of the results thereof, must be kept if we would have our work anything else but spasmodic; that different relief agencies, discharging the same or a similar function in one locality, will do more harm than good unless they act in harmony and with a full understanding of each other's work; that natural ties of kindred are of immense value, and must be conserved and not broken down; that every man's duty is to help himself if he can, and that the best thing his fellowman can do for him, when he needs help, is to help him to help himself; that the acts of every public official should be reported to somebody, so that there shall always be some system of check; that people needing help should get it where they belong; that assisting professional mendicants to travel over the land at the public expense is a bad business - these truisms, so familiar to every member of the Associated Charities, so often ignored by both public and private almoners, are organized into the law which governs the outdoor relief of the state of Indiana.

The new laws seemed to many people, especially public 
officials, too drastic. They cried out: "You will overflow the asylums for the poor!" The students of scientific charity knew that the reduction of outdoor relief had never crowded poor asylums; that since the first crucial experiment, by the heroic Dr. Chalmers in Glasgow, many experiments of the kind have been tried; in this country the notable ones being those of Brooklyn, Indianapolis, New York, Philadelphia, Cincinnati, and Chicago; that the results of such experiments had always been a reduction of pauperism and little else, when outdoor relief had been cut off or reduced.

At the Indiana State Conference of Charities in I899, a few months after the law had gone into effect, but before its results could be measured, the most doleful forebodings were heard. To double or treble the population of all the poor asylums of the state was among the mildest evils to be expected. The author of the law, and the statesmen who enacted it, were called visionaries, fanatics, impracticables, hard-hearted, and cruel. They bided their time; they told their critics to wait and see. They were serene in the fact that, although all the laws of social science are not yet known, yet some of them are, and those are as certain as any other of the laws of nature.

In December, I900, the state conference met again. Among the papers presented was a report upon the workings of the new poor-relief law of I899. The story was simple, brief, and convincing. A comparison was made of the total expenditures for the state for outdoor relief and medical charity of the years I 895 and 1900. The comparison was as follows:

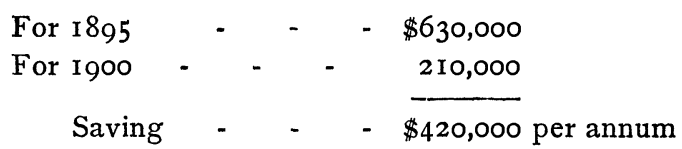

or exactly two-thirds of the total for 1895 . At the same time the number of inmates in county poor asylums had diminished from 14.8 in each 10,000 to 12.3 in each I0,000 of the total popution of the state.

The money test is perhaps not the best test of a social reform, yet it is a true one as far as it goes. But who shall say what 
shall be the value of the saving we may expect in manhood and womanhood in lessening the blighting and degrading effects of pauperism which the new law will make possible when it is better known and acted on? When we dwell on this side of the question, it makes us pause as to whether we should call this result of ten years' slow, steady, patient work a minor reform. It was the work of a board of state charities, begun by one secretary, carried on by a second, and completed by a third; never hasting, never resting, steadily pressing on, always ready for each opportunity to gain a step, even a small one. Is it any wonder that at the state conference last mentioned, when the third secretary of the sequence made the report, the second one should turn to the first, who sat just behind him, and say: "Old man, life has its compensations"?

FORT WAYNE, IND.

Alexander Johnson. 